\title{
Poesia cantada i teatre a la Catalunya del Barroc i el seu context cultural
}

\author{
Sung poetry and theatre in Baroque Catalonia and its cultural \\ context
}

\author{
GASTON GILABERT \\ gastongilabert@gmail.com
}

Universitat de Barcelona

El desconeixement de l'art poeticomusical del Barroc a partir tant d'obres en llengua catalana com en castellana és palès en la majoria d'edicions crítiques de poesies, obres teatrals i cançoners i bona part d'articles científics que fan filòlegs, musicòlegs i historiadors per separat. La poca tradició que tenen els estudis interdisciplinaris a la península ibèrica -en comparació amb el que succeeix en altres latituds- podria explicar la mancança d'atenció crítica en tant que mirada de conjunt als textos poètics, teatrals i musicals. A propòsit dels autors i compositors del Siglo de Oro, les particularitats d'aquest tipus de llenguatge poeticomusical han estat reivindicades i treballades sobretot en les tres darreres dècades, amb estudis normalment dedicats als mateixos grans noms, sense una vocació de sistematització i amb llacunes. Ens trobem, doncs, als inicis de l'exploració i interpretació d'aquestes composicions polièdriques de l'Edat Moderna en llengua castellana; en canvi, pel que fa als estudis interdisciplinaris aplicats a les produccions literàries en llengua catalana, el territori és pràcticament verge, fins i tot en relació a grans autors com Francesc Fontanella. 
Durant el Barroc peninsular i europeu la música ho abastava tot i gaudia d'una gran vitalitat. Si l'investigador va a les fonts manuscrites i impreses de relacions de notícies de l'època, trobarà sovint l'ingredient musical en les vides de les persones des del naixement fins a la mort, en els ritus socials -siguin populars o aristocràtics-, en l'àmbit religiós com en el profà, en la feina dels camperols i en les accions reials de propaganda política, en la solitud de les cambra individual i en espais on es reuneix la col lectivitat. L'Edat Moderna és particularment interessant perquè, a banda de totes les produccions culturals amb participació de cantants que es donen en les diferents tradicions nacionals, Itàlia farà que tota Europa es vegi immersa en experimentacions poeticomusicals, principalment des que la Camerata Bardi inventa l'òpera en llurs investigacions sobre la tragèdia grega. Sense ànim de ser exhaustius, podríem parlar també de la importància en la mateixa època d'altres gèneres amb versos cantats com el villancet, el goig, la comèdia, el ballet de cour, la sarsuela, l'oratori, l'acte sacramental, la festa de maig, la lloa, etc.

El desenvolupament de la impremta en la mateixa època ha condicionat la cultura dels nostres dies, profundament logocèntrica i escritocèntrica, fins al punt que molts lectors actuals s'enfronten a textos poètics i dramàtics de la Modernitat -però també de l'Antiguitat i de l'Edat Mitjana, per exemple- com si no hi hagués una dimensió oral que vivifiqués el cadàver de la lletra escrita, com si el cicle de la producció de significat acabés exclusivament en els ulls. Lluny d'aquest monopoli de l'element visual a través del qual la font literària se'ns manifesta avui en arxius i biblioteques, cal que l'investigador amplii horitzons interpretatius i pensi en un agermanament d'arts i de manifestacions culturals anterior a la radical especialització científica que des del segle XIX abandera les nostres universitats. Moltes de les obres poètiques i teatrals que s'analitzen únicament des de la filologia, realment anaven acompanyades de música, i aquest coneixement pot condicionar el significat específic i global del text literari, fins i tot encara que no haguem conservat la partitura. De la mateixa manera, moltes de les partitures que les facultats de musicologia jutgen des de la pretesa autonomia de la font musical necessitarien una confluència de mirades des d'altres disciplines històriques amb la finalitat de posar sobre la taula noves hipòtesis d'interpretació. Amb un enfocament interdisciplinari podem saber, per exemple, si el to d'un poema és burlesc, si un compositor o un autor rep una influència determinada, si l'actriu plora mentre executa un monòleg o si aquella partitura té un efecte de mirall o contrast amb el tema principal de l'obra literària, entre moltíssimes altres materialitzacions, en una casuística tan variada com els talents artístics creadors.

Amb la voluntat d'il luminar diferents possibilitats d'interrelació entre música i text poètic o teatral, hem fet la selecció dels textos científics que conformen aquest monogràfic. El Barroc, entès en sentit ampli, delimita el marc temporal i el ventall estètic dels treballs, de manera que, encara que el gran protagonista sigui el segle XVII, les arrels immediates d'alguns gèneres, recursos o condicionaments històrics es busquen al segle precedent $\mathrm{i}$ alguns dels fruits més madurs es troben a principis del posterior, malgrat que -abans, durant i després- lluitin amb altres propostes estètiques. Des del punt de vista lingüístic i geogràfic, no hem volgut acotar 
la recerca només als àmbits del català i de Catalunya -per més que siguin el més referenciatsdegut a la rellevància dels fluxos artístics i de certes manifestacions culturals en altres indrets de la península que, per proximitat geogràfica o temàtica, ajuden a entendre el context català. Un exemple d'aquest fet seria la reflexió sobre el concepte de to humà o de comedia nueva que triomfa a la península ibèrica o la Guerra dels Segadors i la de Successió, que apareixeran com a teló de fons de múltiples cançons en llengua castellana i catalana, escrites dins i fora de Catalunya.

Bona part dels treballs aquí reunits tenen el seu origen en el VII Col loqui Internacional Problemes i Mètodes de Literatura Catalana Antiga: "Les Confluències Artístiques en la Literatura Barroca", organitzat pel grup de recerca NISE-Literatura Catalana de l'Edat Moderna i celebrat a la Universitat de Girona de l'1 al 3 de març de 2017. En companyia d'altres textos pensats ex novo, algunes de les ponències presentades en aquella ocasió, degudament reelaborades com articles científics i sotmeses a la subsegüent avaluació, integren aquest monogràfic que posem a disposició de la comunicat científica i del lector curiós, amb la convicció de que constitueix un pas de rellevància per als estudis interdisciplinaris aplicats a la cultura de l'Edat Moderna.

Comença el monogràfic amb la contribució de Joan Carles Gomis Corell, que estudia el gènere dels goigs fent un panorama amb epicentre a la ciutat de València a partir del desenvolupament de la impremta. L'autor reflexiona no només sobre les interaccions de poesia i música presents en els goigs, sinó que afegeix una tercera dimensió artística al gènere devocional amb l'estampació d'imatges, pràctica que es popularitzaria amb l'objectiu d'estimular la pietat dels fidels. Tradicionalment s'ha exemplificat amb l'emblemàtica aquest tipus de gèneres híbrids entre paraula i imatge de l'Edat Moderna, de manera que caldria fer un lloc als goigs, on les històries es canten i es pinten, com demostra Gomis Corell en les seves tesis, que inclouen la reproducció d'estampes.

La poesia musicada del Barroc és l'objecte d'estudi del treball de Lola Josa, en què aprofundeix en les implicacions dels tons peninsulars en relació a una idea harmoniosa de la natura que s'aprecia clarament a la poesia lírica i dramàtica d'ambient pastoral. El to barroc, de la mà amb el lirisme bucòlic, arribarà a ser una de les tipologies més importants de la història interdisciplinària de la poesia i de la música i, a través d'un llenguatge precís, conformarà un codi que explotaran compositors, poetes i dramaturgs per extasiar l'oïda de l'auditori amb el vers cantat.

La figura de Francesc Fontanella, com a dramaturg més rellevant del Barroc català, és l'única que ha estat objecte de dos estudis diferenciats: un vinculat a la seva poesia i un altre al seu teatre. El poeta barceloní conjuga la música amb els dos gèneres literaris, cosa que confirma no només llur cultura musical, sinó que també demana a la investigació actual un enfocament comú de filòlegs i musicòlegs per il luminar les diferents estratègies poeticomusicals que feia servir en les seves obres, independentment del gènere emprat, i posar-les en relació amb les fites peninsulars i europees del moment. 
El primer dels articles de Fontanella fa referència a la poesia lírica. Josep Pujol i Coll recupera el Vexamen fontanellà per assenyalar la presència del gran compositor montserratí Joan Cererols (16181680), amb la particularitat de que apareix com a poeta en català i no com a músic o compositor, que és el que cabria esperar. Aquesta dada posa de manifest l'agermanament de poesia i música en els creadors barrocs i podríem pensar en hipòtesis sobre la música en les obres de Fontanella: tenia ell també ambdues habilitats? Cererols podia haver treballat amb ell? Sigui com sigui, Pujol i Coll fa un recompte de les poesies de Fontanella amb vincles musicals, centrant-se sobretot en llurs villancets. A causa de l'absència de partitures, el musicòleg proposa melodies que encaixen amb les seves lletres per a cantar, com a contrafacta, un mode al que recorrien amb freqüència els poetes peninsulars del Siglo de Oro.

L'autor d'aquestes línies introductòries és també el del segon dels treballs dedicats a Fontanella, ara, però, com a poeta dramàtic, a partir de llur Lloa per a la Tragicomèdia d'amor, firmesa i porfia. Després d'una proposta de classificació quant a gènere breu i una reflexió sobre el circuit teatral en què es deuria representar la peça, es fa una anàlisi de la seva estructura amb consideracions mètriques, temàtiques i expressives. A través de diferents conceptes poeticomusicals vinculats amb passatges de la lloa fontanellana, es proposa finalment una nova lectura de la peça d'acord amb la importància funcional que el poeta va atorgar a l'ingredient sonor.

Si els dos treballs anteriors es refereixen al vers cantat en el context de la Guerra dels Segadors que va determinar la biografia de Fontanella, els darrers dos articles del monogràfic es centren en obres que tradueixen artísticament la situació política de la transició entre finals del segle XVII, amb la Guerra dels Nou Anys i la Guerra de Successió, i principis del XVIII, amb el triomf de Felip V. La poesia musicada del Barroc, dintre i fora de l'espectacle teatral, mostra també la seva vitalitat i popularitat quan es posa al servei de la propaganda política o quan funciona com a noticiari, per difondre diferents interpretacions de fets de radical actualitat.

Álvaro Torrente viatja a la Barcelona de 1696 per a recuperar els villancets policorals i les festivitats oficials que es van celebrar per la recuperació de la salut de l'últim rei de la Casa d'Habsburg. El musicòleg analitza els versos on es canten missatges polítics i doctrinals, al mateix temps que extreu característiques de les partitures conservades -dues d'elles atribuïdes a Francesc Valls, un dels màxims exponents de la música barroca a Catalunya-. A banda de donar per primera vegada a la comunitat científica les explicacions detallades d'aquestes peces i el context festiu en què es van desenvolupar, edita en un annex els villancets en qüestió, un patrimoni de gran valor per conèixer aquest tipus de manifestacions culturals de la Barcelona barroca.

Tanca el present monogràfic un treball protagonitzat per un gènere espectacular barroc en què la poesia i la música ens apareixen per se orgànicament lligades: la sarsuela. Jordi Bermejo reflexiona sobre la primera dècada del segle XVIII, plenament barroca, a partir de l'obra d'Antonio de Zamora Viento es la dicha de amor, de 1708, on el vers cantat vehicula una qüestió tan delicada com el tractament de Felip V als perdedors de la Guerra de Successió. Zamora confia a l'element 
poeticomusical en les seves festes reials -que convocaven les famílies més poderoses de l'Estatl'expressió lírica de les preocupacions de tota una societat, en aquest cas, el penediment, la restitució i la lleialtat.

En conclusió, els sis treballs d'aquest monogràfic volen donar a conèixer diferents implicacions de la relació entre literatura i música durant el Barroc a Catalunya, però també amb implicacions a les terres de parla catalana $i$ al conjunt de la península. Es tracta d'una aposta ferma per la interdisciplinarietat i per l'apertura d'horitzons a l'hora d'emetre judicis estètics davant la complexitat que suposa el vers cantat en el ventall de motlles que el poden acollir. En definitiva, historiadors, filòlegs i musicòlegs han treballat consultant alhora fonts històriques, literàries i musicals, per a donar, a la comunitat científica $i$ al lector en general, un conjunt d'exemples i d'anàlisis que permetran valorar millor el context en què es van produir i les relacions entre poetes i compositors a l'Edat Moderna. 